\title{
HYPONATRAEMIA DURING TRANSURETHRAL SURGERY
}

\author{
G.M. AASHEIM, M.D. ${ }^{*}$
}

TransurethiRal PROSTATIC RESECTION presents problems peculiar to this procedure due to the necessity of irrigating the surgical field continuously with a non-electrolyte solution. The most common complications are: (1) intravascular absorption of water, and (2) extravasation of water into tissues outside the bladder or the prostatic capsule. The result is dilution hyponatraemia which, unless promptly diagnosed and treated, causes serious dysfunctions which may progress to death.

Unfortunate experiences with two patients have emphasized the inadequacy of the "routine" monitoring traditionally used and the need for more appropriate techniques for evaluating these patients. In this report we detail our clinical experience and review the literature to emphasize the important aspect of the subject.

\section{Clinical Material}

For this report the records of 146 patients who underwent transurethral prostatic resection were reviewed. The sequence of the events in two patients who died and the calculations made after their deaths are first described.

\section{Case I}

AKF was an 80 -year-old man with prostatism, chronic obstructive pulmonary disease, and bronchitis with normal pre-operative electrolytes and haematocrit. A transurethral resection was performed under spinal anaesthesia. The patient tolerated the procedure well until 90 minutes had passed, at which time he complained of abdominal pain and became restless. A small perforation in the prostatic capsule was noted. The procedure was carried to completion. However, at this point ( $1 \frac{12}{2}$ hours later) the patient became unresponsive and shortly thereafter his blood pressure fell. His abdomen was distended. Serum electrolytes were then measured and were $\mathrm{CO}_{2} 16 \mathrm{mEq} / \mathrm{liter}, \mathrm{Cl} 70 \mathrm{mEq} /$ liter, $\mathrm{Na} 90 \mathrm{mEq} / \mathrm{liter}$, and $\mathrm{K} 4.0$ $\mathrm{mEq} /$ liter. Two units of blood were given and an intravenous infusion of hypertonic saline was started. The hypotension did not respond to these measures, nor to large doses of metaraminol (Aramine ${ }^{\circledR}$ ). The pulse became weak, signs of pulmonary oedema appeared and the patient had cardiac arrest. Resuscitation efforts failed. At autopsy a perforation was found in the prostatic capsule. There was marked local oedema. Ascitic fluid was present in the peritoneal cavity and there was marked acute pulmonary oedema with bilateral pleural effusions. There also was acute pulmonary and hepatic congestion. Blood samples taken from the heart were described as "distinctly watery". All these findings were considered consistent with hypervolaemia secondary to absorption of irrigating fluid.

"Veterans Administration Hospital, and Department of Anesthesiology, University of Washington, Seattle, Washington, U.S.A. 


\section{Calculations}

The approximate amount of fluid absorbed was estimated by determining the amount of fluid diluent that would be required to bring about the change in sodium concentration exhibited by this patient. The following assumptions were made: (1) that in the relatively short period of time involved the fluid absorbed would be distributed through the extra-cellular fluid (ECF) compartment only, (2) that the extra-cellular fluid compartment is equivalent to 20 per cent of the body weight, and (3) that ECF sodium concentration is equal to that of the serum. Weight immediately prior to the operation was $61 \mathrm{~kg}$. Unfortunately, no post-mortem weight was obtained. If the pre-operative ECF is 20 per cent of body weight, then in this case it was $0.2 \times 61$ or $12.2 \mathrm{~kg}$ which is approximately 12 liters. The postoperative ECF will then equal 12 liters plus the increment of absorbed fluid. Since the total amount of the solvent (ECF) is increased, the increment of fluid ( $x$ ) can be calculated by the following equation: $143 \mathrm{mEq} /$ liter $\times 12$ liter $=90 \mathrm{mEq} /$ liter $\times(12$ plus $x)$. Thus $x=7.1$ liters. By a similar calculation using the chloride value, the increment in ECF is 5.8 liters. The estimation was also made using the change in concentration of Sorbitol, in which case, the result was 6.4 liters. Therefore, the total amount of irrigation fluid absorbed was in the range between 5.8 and 7.1 liters.

\section{Case II}

GWR was a 70-year-old man with chronic renal disease, adult diabetes, and congestive heart failure. Pre-operative laboratory examination showed the following: Serum Cl $105 \mathrm{mEq} /$ liter, Na $143 \mathrm{mEq} /$ liter, K $3.4 \mathrm{mEq} /$ liter, BUN $100 \mathrm{mg} \%$, haematocrit 27 per cent, and fasting blood sugar $112 \mathrm{mg} \%$. He was brought to the operating room for transurethral resection of the prostate after conservative treatment with catheter drainage of the bladder for approximately $1 \frac{1}{2}$ years to improve his general condition. A spinal anaesthetic with tetracaine produced analgesia to T-8. After transurethral resection lasting 3 hours, the operation was terminated due to venous oozing. The patient developed an unexplained elevation of blood pressure during the operation. Serum sodium was $122 \mathrm{mEq} /$ liter immediately post-operatively. He was placed on a low-salt diet because of bilateral pulmonary râles and after seventeen days he was returned to the operating room for completion of the transurethral resection. Epidural anaesthesia was given. Blood pressure was stable until one and a quarter hours into the operation when he suddenly became hypotensive and complained of chest pain. Temporary relief was obtained with oxygen, vasopressors, and blood. At two hours of resection time, the patient became unmanageable and required general anaesthesia for an additional 45 minutes of the operation. Blood pressure was supported with ephedrine, four units of blood, and three bottles of plasma. After $5^{\frac{1}{4}}$ hours of resection, electrolyte measurement showed: $\mathrm{Na}+83 \mathrm{mEq} /$ liter, $\mathrm{Cl}^{-} 56 \mathrm{mEq} /$ liter, and $\mathrm{K}+3.5 \mathrm{mEq} /$ liter. Supportive therapy consisted of digoxin, isoproterenol, $2000 \mathrm{cc}$ hypertonic saline, and $90 \mathrm{mEq}$ of sodium bicarbonate. He remained unconscious with dilated and non-reactive pupils for nine hours in the recovery room, after which he expired. During this time he developed pulmonary oedema and a generalized bleeding problem. Autopsy was not done. 


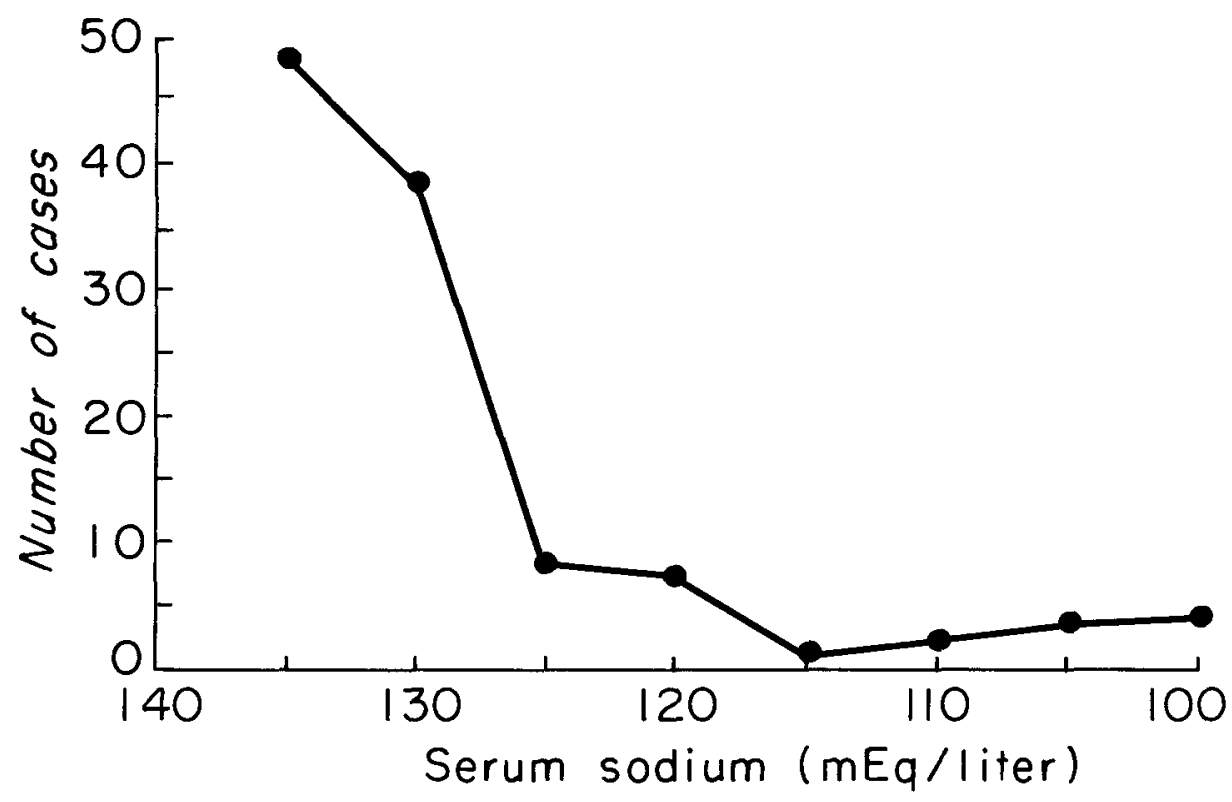

Figure 1. Number of cases plotted against serum sodium concentrations.

\section{Post-Mortem Calculations}

His weight on the day before the operation was $55 \mathrm{~kg}$ with serum sodium of 115 $\mathrm{mEq} /$ liter. If the pre-operative ECF was 20 per cent of body weight, then ECF $=0.2 \times 55$ or 11 kilograms $=11$ liters. Post-operative ECF $=11$ liters plus absorbed fluid. Since post-operative sodium was $83 \mathrm{mEq} /$ liter, $115 \mathrm{mEq} /$ liter $\times 11$ liters = $83 \mathrm{mEq} /$ liter $\times(11+\mathrm{x})$ liters. Consequently $\mathrm{x}=4$ liters. Similar determinations using the chloride value gives an increment in ECF of 3 liters.

These two unfortunate experiences within one year, in which the patients expired due to hyponatraemia, alerted us to the inadequacy of routine monitoring of these patients. Therefore, during the last four years, serum sodium determinations have been done hourly or more frequently if indicated by signs or symptoms. In reviewing the records of the 144 other patients, complete data were available in 104 cases. These data have been analyzed and are shown in Figure 1 through 3. As noted in Figure 1, 86 or 82.6 per cent of the group had serum sodium of $130 \mathrm{mEq} /$ liter or above. Figure 2 shows that in only a small number of patients, the resection lasted more than two hours. Figure 3 reveals that a considerable number of patients developed hyponatraemia within half an hour of the start of operation.

\section{Discussion}

Optimum management of patients undergoing transurethral prostatic resection requires consideration of: (1) the type of anaesthesia, (2) the use of the right solute in the continuous irrigation essential to distend the prostatic urethra or bladder and improve visibility for the surgeon, (3) the duration of the operation, and (4) prompt diagnosis and treatment of hyponatraemia if this occurs. 


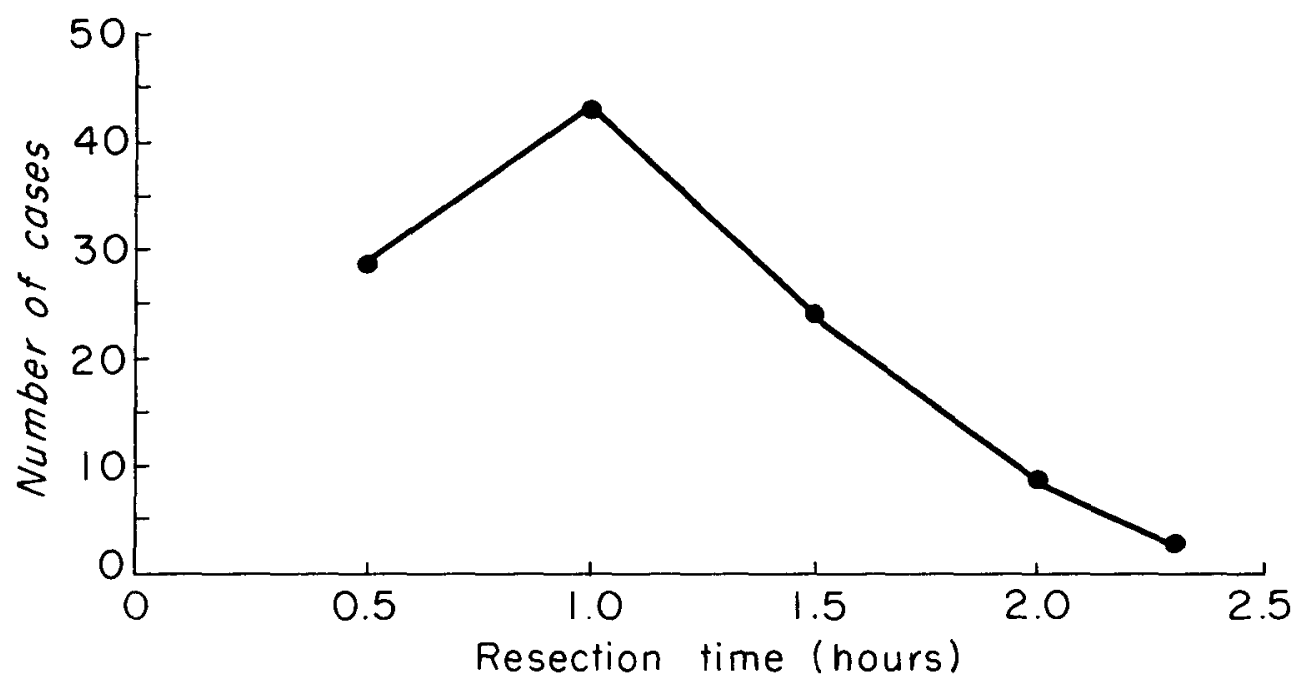

Figure 2. Number of cases plotted against operating time in hours.

\section{Anaesthetic Management}

We prefer a subarachnoid block because it facilitates recognition of complications. The patients are given whatever pre-anaesthetic medication is considered appropriate, with care being taken to avoid overdose. Subarachnoid block is achieved with tetracaine, made hyperbaric with dextrose and using a technique which produces analgesia at T-8 to T-10 as the optimal level. If a subarachnoid block is contra-indicated because of the patient's refusal or active (or potentially active) neurological disease, light inhalation anaesthesia is administered. General anaesthesia eliminates subjective symptoms and may mask objective signs of serious complications. In addition to the intravenous infusion of Lactated Ringers Solution, blood is given whenever it is indicated. In addition to the frequent measurements of blood pressure, pulse, respiration and vital signs, monitoring of the patients includes routine blood gas determinations to minimize the risk of hypercarbia and sodium determination done hourly or more frequently when there are any signs or symptoms of hyponatraemia. Although increases in systolic and diastolic blood pressure are considered to be the classical signs of hypervolaemia, ${ }^{1}$ we believe that any change in vital sign is an indication for an immediate serum sodium determination. Recently an abrupt fall in blood pressure during inhalation anaesthesia prompted immediate blood sampling and the serum sodium after 15 minutes of resection was $113 \mathrm{mEq} /$ liter whereas the pre-operative serum sodium had been normal. Because of our suspicion that this result might be due to laboratory error, it was repeated immediately and was then reported $100 \mathrm{mEq} /$ liter. At this time it was difficult to ventilate the patient's lungs and he was apparently convulsing. Cessation of the operation and the anaesthetic resulted in a prompt diuresis and a rise in the serum sodium level to $110 \mathrm{mEq} /$ liter within one hour and to $130 \mathrm{mEq} /$ liter within two hours. Berg et al. ${ }^{2}$ found in dogs that serum $\mathrm{K}^{+}$was slightly lowered but remained within normal limits. This has been our experience also. 

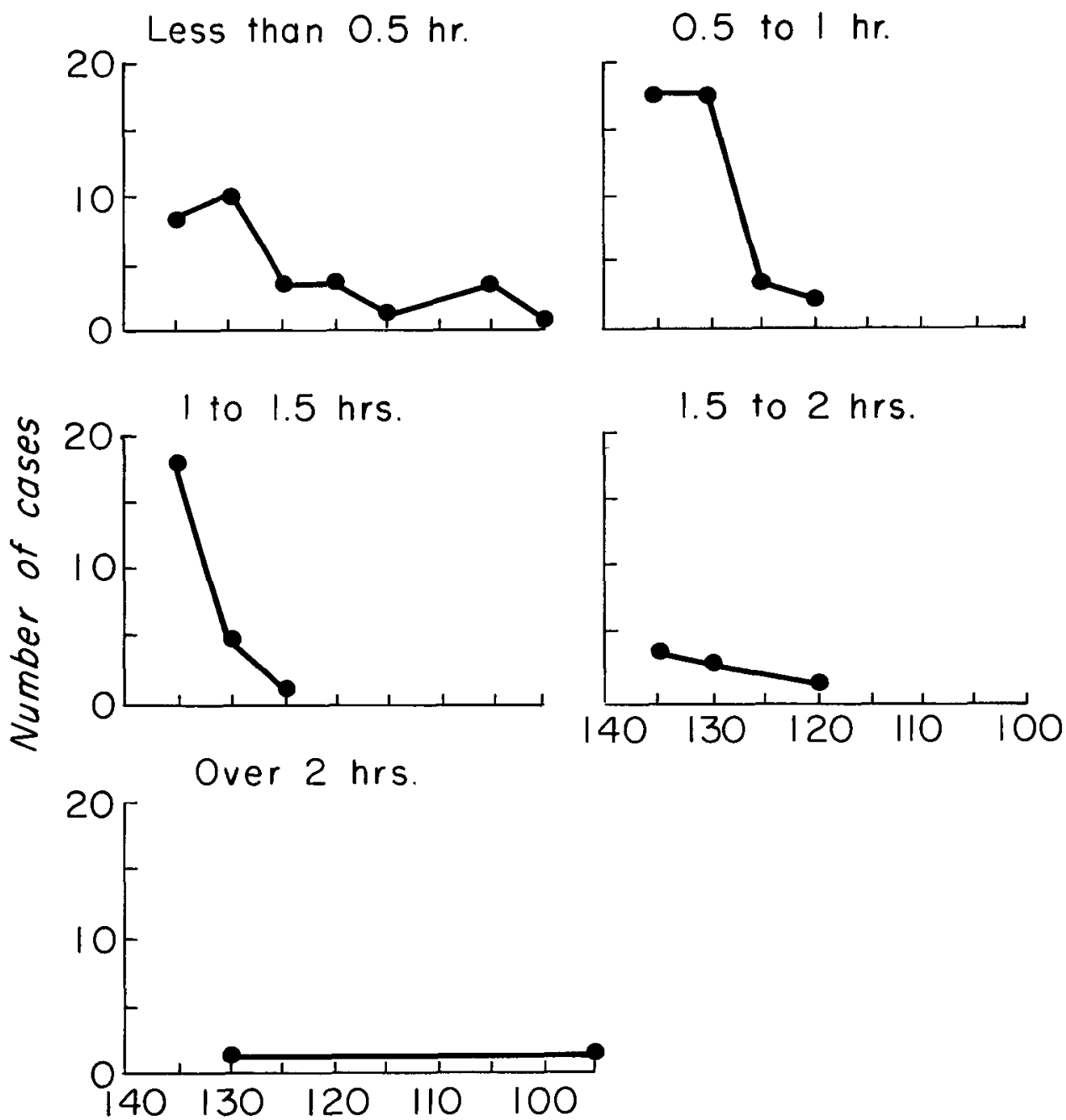

Figure 3. The number of cases plotted against serum sodium concentrations and related to various durations of operation as indicated.

\section{Type of Solution}

Non-electrolyte solutions are necessary to allow coagulation of tissues by the electrocautery unit. Berg $e t$ al. ${ }^{2}$ have found that both intravascular absorption of water and extravasation of water into tissues outside the bladder can result in hyponatraemic shock. If non-electrolyte fluid of any kind is extravasated into the peritoneal cavity or extraperitoneal space through a perforation, electrolytes will diffuse into this pool from the extracellular fluid. Cytal solution was used for bladder irrigation in our cases. When diluted with nine parts of distilled water, it contains $2.70 \mathrm{gm}$ Sorbital and $0.54 \mathrm{gm}$ Mannitol. It contains no preservative and is isotonic, non-electrolytic, and non-nitrogenous. Since it is non-electrolytic, absorption of large quantities leads to haemodilution. Hydrostatic pressure of the irrigat- 
ing solution is an important factor in determining the amount of absorption. Because it is isotonic, there is no haemolysis. Berg ${ }^{2}$ reports that absorption of Cytal ${ }^{8}$ does not cause water intoxication despite marked depression of sodium levels and that the treatment of choice is the withholding of additional fluids until the excess is eliminated.

\section{Duration of Operation}

The duration of the operation has been thought to be important. ${ }^{1}$ However, we have had severe falls in serum sodium levels within a short time and in one patient the sodium fell from $136 \mathrm{mEq} /$ liter to $104 \mathrm{mEq} /$ liter after only 20 minutes of resection, with a gain in weight from 118 to 125 pounds. This increase of 7 pounds represents a fluid gain of somewhat more than 3.3 liters. Lack of time relationship in the production of hyponatraemia has also been shown by Ceccorelli et al. ${ }^{3}$ Therefore, time restriction is no guarantee against the development of this complication.

Masloff et al. ${ }^{4}$ state that weight gain is the most reliable indication of fluid absorption. This, however, is impossible to monitor during the operation when an immediate diagnosis may be crucial.

Central venous pressure monitoring has been suggested as a reliable guide, but in our patients this has proven not to be so. This observation has been corroborated by others. ${ }^{1,5}$

\section{Symptomatology of Dilutional Hyponatraemia}

A serum sodium level of $120 \mathrm{mEq} /$ liter appears to be borderline between mild and severe reactions. ${ }^{6}$ Restlessness is an early symptom and may be associated with irritability and confusion. Instead of treating the symptom with sedation, an attempt must be made to determine the cause, and if no obvious cause is found, an immediate serum sodium determination is indicated.

Changes in blood pressure and pulse rate occur frequently. Electrocardiographic changes are seen when the sodium falls to $115 \mathrm{mEq} /$ liter. Such changes are characterized by widening of the QRS complex and by an ST segment elevation. Seizures occur at serum sodium levels of $102 \mathrm{mEq} /$ liter. Below a serum sodium of $100 \mathrm{mEq} /$ liter ventricular tachycardia or fibrillation may occur. This can be reversed immediately by the administration of sodium.

\section{Treatment}

Successful treatment depends upon early detection of hyponatraemia. If the surgical procedure is terminated, the patient has a prompt diuresis. The serum sodium level is followed every half-hour to one hour post-operatively and no other treatment has been necessary. This has been reported also by Pierce ${ }^{7}$ who has also reported the treatment of patients who fail to have diuresis. Treatment of other complications are reported by Marx et al. ${ }^{1}$ However, with early diagnosis and prompt termination of the operation, no further complications ( such as pulmonary oedema, pleural effusion, and ascites) have developed. 


\section{SUMMARY}

If early warning of intravascular fluid overload can be given to the surgeon during transurethral prostatic resection the operation can be terminated and serious complications can be avoided. This warning can be given by carrying out serial serum sodium determinations which, by indicating hyponatraemia, have proved to be a valuable adjunct to cardiovascular monitoring during transurethral operations.

\section{RÉSUMÉ}

Nous rapportons deux cas de décès dus à l'irrigation continue durant la prostatectomie transurethrale. Les morts sont dues à une hyponatremie grave. A la suite d'une étude de 104 malades surveillés par des déterminations horaires de sodium sérique, la fréquence d'un sodium sérique inférieur à $130 \mathrm{mEq} /$ litre a été de 17.4 pour cent. Nous sommes d'avis qu'il est possible d'éviter de sérieuses complications en exerçant une surveillance horaire du sodium sérique et même plus fréquemment si le malade devient symptomatique. Si le malade présente une hyponatrémie de dilution, il faut arrêter l'opération, et, alors, le malade va établir une diurèse qui va lui permettre d'éliminer l'excès d'eau.

\section{REFERENCES}

1. MARx, G.F. \& Orkin, L.R. Complications associated with transurethral surgery. Anesthesiology 23: 802-813 (1962).

2. Berg, G., Fedor, E.J., \& Fisher, B. Physiologic observations related to the transurethral resection reaction. J. Urol. 87: 596-600 (1962).

3. Ceccarelli, F.E. \& Mantell, L.K. Studies on fluid and electrolyte alterations during transurethral prostatectomy I. J. Urol. 85: 75-82 (1961).

4. Masloff, J.I., Milan, J.H., \& Bunts, R.C. Fluid and electrolyte changes associated with transurethral prostatic resection. Southern Med. J. 59: 1203-1208 (1966).

5. Huf, D., Koenrg, J., \& Hamelburg, W. Fluid absorption during transurethral prostatic resection. Anesthesiology 23: 152 (1962).

6. HoYt, H.S., Goebel, J.L., LeE, H.I., \& Schoenbrod, J. Types of shock-like reaction during transurethral resection and relation to acute renal failure. J. Urol. 79: 500-506 (1958).

7. Pierce, J.M., Jr. The treatment of water intoxication following transurethral prostatectomy. J. Urol. 87: 181-183 (1962). 